\title{
Assessment of the diabetogenic drugs alloxan and streptozotocin as models for the study of immune defects in diabetic mice
}

\author{
G. N. Gaulton ${ }^{1}$, J. L. Schwartz ${ }^{2}$ and D. D. Eardley ${ }^{3}$ \\ ${ }^{1}$ Department of Pathology, Harvard Medical School and ${ }^{2}$ Department of Cancer Biology, Harvard School of Public Health, Boston, \\ Massachusetts, and ${ }^{3}$ Department of Biological Sciences, University of California Santa Barbara, Santa Barbara, California, USA
}

\begin{abstract}
Summary. The efficacy of the diabetogenic drugs streptozotocin and alloxan were evaluated as models for the study of immune defects associated with diabetes. Streptozotocin- or alloxan-treated mice, with a stable hyperglycaemia of $25-33 \mathrm{mmol} / 1$ plasma glucose, were severely impaired in their ability to mount antibody forming, mitogenic, or delayed-type hypersensitivity responses in vivo. Treatment of alloxan-diabetic mice with insulin in vivo completely reversed all immune defects, while insulin treatment of streptozotocin-diabetic mice restored immune function to only $70-80 \%$ of normal levels. Results obtained by viability measurements and in vitro biological assays of lymphoid function, including proliferation in response to T- and B-cell mitogens, the production of interleukin- 2 by $T$ cells, and the production of interleukin- 1 by macrophages indicated that direct exposure to alloxan for $48 \mathrm{~h}$ (at concentrations $\leq 14 \mathrm{mmol} / \mathrm{l}$ ) had no adverse effects on lymphoid activity, while exposure to streptozotocin was routinely toxic at concentrations $\geq 1 \mathrm{mmol} / \mathrm{l}$. Both alloxan
\end{abstract}

and streptozotocin exhibited strong toxicity in vitro for isolated pancreatic islet cells. Finally, lymphocytes from streptozotocin-diabetic mice, or cells incubated in vitro with streptozotocin, contained numerous chromosomal abnormalities indicative of DNA strand breakage. Such abnormalities were absent in alloxan-diabetic mice and in cells incubated with alloxan in vitro. These results indicate that immune dysfunction associated with streptozotocin is attributable to direct and irreversible impairment of lymphoid cell function and viability. In contrast, immune dysfunction associated with alloxan-diabetes appears to be a consequence of the diabetic state. Thus, alloxan- but not streptozotocin-diabetes provides a useful model for evaluating immunological changes associated with hyperglycaemia and diabetes.

Key words: Alloxan, streptozotocin, lymphoid toxicity, diabetes, immune function.
Studies conducted over the past 40 years have documented that poorly managed diabetic patients suffer impairment of both cellular and humoral immune responses [1-4]. While the majority of this work accurately describes the general immunodeficiency syndrome, precise mapping of the cells which are primarilly affected, and of the relationship between these cells and normal lymphoid cells in the regulation of immune responses, has not been accomplished. In part, these difficulties trace to the lack of a clearly defined murine model for evaluating the immune system of Type 1 (insulin-dependent) diabetic subjects. Both of the genetically linked murine diabetic syndromes $(\mathrm{Ob}$ and $\mathrm{db}$ ) more closely resemble Type 2 (non-insulin-dependent) diabetes in their aetiology. Thus, from the point of view of analyzing altered immunity in the context of the effects of diabetes, these models suffer the added confusion of immune autoreactivity as a possible cause of diabetes [5].

The diabetogenic agents alloxan and streptozotocin (STZ) have provided the most reliable models of Type 1 diabetes in mice [6] and have been widely employed to establish murine models for the analysis of secondary diabetic phenomena such as altered immune function and ocular pathology. Both drugs exhibit toxicity for B islet cells which is linked to their capacity to accumulate rapidly in these cells and to the high sensitivity of the $B$ cell towards peroxidases relative to other tissues [6-9]. Several studies have reported an impairment of both humoral and cellular immune functions in alloxan- and STZ-diabetic mice [10-13]. However, conflicting reports exist which question the specificity of these diabetogenic agents; most notably, Nevalainen and Hoftiezer [13], and Nichols et al. [14] have detected a direct toxicity of STZ for thymic components of the immune system. These reports have prompted our analysis of the direct effects of STZ and alloxan on the cellular components of the immune system as contrasted to pancreatic islet cells.

\section{Materials and methods}

\section{Animals}

Inbred DBA/2J female mice (Jackson Laboratories, Bar Harbour, Maine) aged 8-12 weeks, weight $20-25 \mathrm{~g}$ were used throughout the experiments. All mice were maintained on Prolab 3000 mouse chow 
(Agway, Syracuse, New York) and water ad libitum. Blood glucose levels of nonfasting mice were $6.5-8.6 \mathrm{mmol} / \mathrm{l}$.

\section{Induction and management of diabetes}

Mice were rendered diabetic by a single intravenous injection of either alloxan (5,6-dioxyuracil monohydrate, $50 \mathrm{mg} / \mathrm{kg}$ body weight) in saline $(150 \mathrm{mmol} / 1 \mathrm{NaCl})$, or STZ (2-deoxy-2-[(methylnitrosoamino)carbonyl -amino(-D-glucopyranose), $150 \mathrm{mg} / \mathrm{kg}$ body weight) in $10 \mathrm{mmol} / \mathrm{l}$ citrate buffer ( $\mathrm{pH} 4.5$ ). Mortality was $<5 \%$. The metabolic control of diabetic mice was determined by daily weight measurements, measurements of plasma glucose levels, and the levels of pancreatic insulin. Non-fasting whole blood glucose levels were monitored immediately prior to use on days 2 or 5 , using the 0 -toluidine method [15]. Blood was obtained from the paraorbital venous plexus using heparinized capillary tubes. Only mice which showed no overt signs of diabetes and with plasma glucose levels between $25-33 \mathrm{mmol} / 1$ were chosen. Greater than $95 \%$ of these mice displayed elevated glucose levels for at least 21 days after drug injection. Mice with glucose levels $<20 \mathrm{mmol} / 1$ (not used in this study) had a greater than $25 \%$ reversion to normal glucose levels by 21 days. Pancreatic insulin levels were determined by radioimmunoassay as described previously $[16,17]$.

To correlate the doses of alloxan and STZ used in vivo to those in vitro, an approximation of the concentration of alloxan and STZ in the extracellular fluid compartment has been calculated based on murine fluid compartment size as reported by Bernstein [18], and assuming an unrestricted fluid distribution. For alloxan a $50 \mathrm{mg} / \mathrm{kg}$ dose corresponds to a concentration of $1.1 \mathrm{mmol} / \mathrm{l}$, and for STZ $150 \mathrm{mg} / \mathrm{kg}$ corresponds to $1.8 \mathrm{mmol} / 1$. The observations of Lee and Dewitt [19], and Weiss [7] indicate that alloxan and STZ accumulate rapidly and preferentially in the pancreatic islets as compared to lymphatic organs and blood. For example, $60 \mathrm{~min}$ following intravenous injection the levels of pancreatic alloxan are 96 times those in blood, 78 times those in spleen, and 72 times those in thymus [19]. Thus, the estimated concentrations of these drugs in fluid represent values at maximal levels of potential initial exposure to lymphoid cells.

Where indicated, mice were given $0.33 \mathrm{IU}$ insulin (Sigma, St. Louis, Missouri) by intramuscular injection every $8 \mathrm{~h}$. The metabolic control of insulin-treated mice was determined by weight and plasma glucose measurements, and by glucose tolerance tests. Blood for glucose tolerance tests was obtained $60 \mathrm{~min}$ after the intraperitoneal administration of $2 \mathrm{mg}$ of glucose per gram of body weight [17]. Insulin-treated alloxan- and STZ-diabetic mice displayed normal glucose levels after 4 days of management, accompanied by a steady weight gain. Return to weight levels of age-matched normal mice was achieved after 10 days of insulin treatment. Mice shifted off insulin after 4 days of management reverted to previous levels of the diabetic state within 2 days.

\section{Cell isolation}

Pancreatic islets were isolated from mice by the collagenase method of Lacy et al. [20] and were maintained in culture in Dulbeco's modified Eagle's Media (Gibco, Grand Island, New York) supplemented with $10 \%$ fetal bovine sera, $100 \mu \mathrm{g}$ penicillin/streptomycin, $4 \mathrm{mmol} / 1$ glutamine, $25 \mathrm{mmol} / 1$ Hepes (pH 7.2), and $5 \times 10^{-5} \mathrm{~mol} / 12$-mercaptoethanol at $37{ }^{\circ} \mathrm{C}$ in $5 \% \mathrm{CO}_{2}$. Spleen and thymus cells were isolated by sterile excision from freshly killed mice. Organs were washed briefly in RPMI 1640 media (Gibco), supplemented as above then teased apart between two frosted glass slides. Cells were washed three times and harvested by centrifugation at $800 \mathrm{~g}$ for $10 \mathrm{~min}$. Splenic macrophages were isolated by the method of Cowing et al. [21] with adherence onto glass Petri dishes for $2 \mathrm{~h}$ at $37^{\circ} \mathrm{C}$ in supplemented RPMI 1640 . Adherent cells were harvested by washing with 1:5000 Versene buffer (Gibco) for $15 \mathrm{~min}$ at $37^{\circ} \mathrm{C}$. Cell viability was determined by counting in a Neubauer haemacytometer (Scientific Products, McGraw Park, Illinois) in the presence of $0.04 \%$ trypan blue as described by Grankvist et al. [22].

\section{Assays in vitro}

Anti-sheep red blood cell antibody responses were conducted using the in vitro haemolytic plaque assay as modified by Cunningham [23] and Eardley et al. [24]. Spleen cells $\left(1 \times 10^{6}\right)$ in supplemented RPMI 1640 were cultured in $200 \mu \mathrm{l}$ microtitre wells for 5 days at $37^{\circ} \mathrm{C}$ in $5 \% \mathrm{CO}_{2}$ in the presence of $0.05 \%$ sheep red blood cells (Pel Freeze, Rodgers, Arkansas). For in vitro experiments alloxan or STZ were added to incubations on day 0 or 3 at concentrations between $0.1-14.0 \mathrm{mmol} / \mathrm{l}$. The mean number of plaque forming cells was calculated from triplicate cultures on day 5 and the data are expressed as plaque forming cells $/ 10^{6}$ spleen cells plated.

Mitogenic assays were conducted in vitro in $200 \mathrm{ul}$ microtitre wells which contained $2 \times 10^{5}$ cells in supplemented RPMI 1640 and either of the mitogens concanavalin A $(2.5 \mu \mathrm{g} / \mathrm{ml}$, Sigma), bacterial lipopolysaccharide $(5 \mu \mathrm{g} / \mathrm{ml}$, Difco, Detroit, Michigan) or phytohaemagglutinin $(5 \mu \mathrm{g} / \mathrm{ml}$, Difco). Alloxan or STZ were added to incubations at the same time as mitogens. Control incubations were conducted in saline (for alloxan) or citrate buffer (for STZ) in the absence of drugs. After $40 \mathrm{~h}$ the reactions were pulsed with $1 \mathrm{uCi}{ }^{3} \mathrm{H}$-thymidine $(6.7 \mathrm{Ci}$ / mmol, New England Nuclear, Boston, Massachusetts) and harvested $8 \mathrm{~h}$ later. The results of quadruplicate experiments are presented.

Interleukin- 2 synthesis was determined in triplicate by incubating spleen cells $\left(2 \times 10^{6}\right.$ cells $\left./ \mathrm{ml}\right)$ in supplemented RPMI 1640 at $37^{\circ} \mathrm{C}$ in the presence of $2.5 \mu \mathrm{g} / \mathrm{ml}$ concanavalin A and alloxan or STZ for $48 \mathrm{~h}$. Supernatants were harvested, filter sterilized, and assayed for interleukin- 2 by the ability to support the growth of the interleukin- 2 dependent line CTLL-2 [25]. CTLL-2 cells $\left(2 \times 10^{4}\right.$ cells in $\left.200 \mu \mathrm{l}\right)$ were incubated for $16 \mathrm{~h}$ at $37^{\circ} \mathrm{C}$ then pulsed with $1 \mathrm{uCi}{ }^{3} \mathrm{H}$-thymidine and harvested $8 \mathrm{~h}$ later.

Whether alloxan or STZ affect interleukin-l synthesis by splenic macrophages was determined by incubating splenic macrophages with $5 \mu \mathrm{g} / \mathrm{ml}$ lipopolysaccharide at $37^{\circ} \mathrm{C}$ in supplemented RPMI 1640, and in the presence of either alloxan or STZ. Supernatants were harvested after $48 \mathrm{~h}$, filtered and assayed for interleukin-l by the phytohaemagglutinin thymocyte proliferation assay as described previously [26].

\section{Assays in vivo}

The ability of alloxan or STZ to inhibit cellular immune responses in vivo was assessed by examining the delayed-type hypersensitivity response to the hapten azobenzenearsonate as described by Bach et al. [27]. Briefly, mice were immunized subcutaneously with $3 \times 10^{7}$ azobenzenearsonate-coupled syngeneic spleen cells. Five days later mice were challenged in the left foot pad with $33 \mu \mathrm{l}$ of azobenzenearsonate salt $(100 \mathrm{mmol} / \mathrm{l})$. Twenty-four hours later the footpad swelling increment (left foot versus right foot) was determined using an engineer's calipers (Fowler, Neuber, Indiana).

\section{Immunofluorescence staining}

To determine the proportions of lymphocyte subpopulations in splenocytes of day 5 alloxan- and STZ-diabetic mice, immunofluorescence studies were conducted. To detect B-cell levels, spleen cell suspensions were stained directly with fluorescein conjugated $\mathrm{F}\left(\mathrm{ab}^{\prime}\right)_{2}$ rabbit anti-mouse immunoglobulin (Miles Laboratories, Naperville, Illinois) then fixed in 1\% paraformaldehyde. T cell levels were obtained by subtraction of B-cell values from those obtained upon staining of spleen cells with mouse anti-theta 1.2 (monoclonal HO13.4) plus fluoresceinated rabbit anti-mouse immunoglobulin. To measure the proportions of T-cell subclasses, T cells were first purified by panning on goat anti-mouse immunoglobulin (Miles) coated plates and the nonadherent fraction was reacted with either mouse anti-Lyt 1.1 or antiLyt 2.1 (a gift of Dr. F. W. Shen, Sloan Kettering Institute, New York, New York) and stained with fluoresceinated rabbit anti-mouse immunoglobulin. For all reactions $1 \times 10^{6}$ cells were incubated with $100 \mu \mathrm{l}$ of the appropriate diluted antibody at $4^{\circ} \mathrm{C}$ for $45 \mathrm{~min}$, washed three times in ice cold balanced salt solution containing $2 \%$ fetal bovine se- 
ra and $0.1 \% \mathrm{NaN}_{3}$, and then incubated at $4{ }^{\circ} \mathrm{C}$ for $45 \mathrm{~min}$ with fluoresceinated rabbit anti-mouse immunoglobulin. Cells were fixed in paraformaldehyde prior to analysis on a fluorescence activated cell sorter.

\section{Lymphocyte karyotype analysis}

Analysis of lymphocyte karyotype was performed on lymphocytes $\left(5 \times 10^{6}\right.$ cells $\left./ \mathrm{ml}\right)$ which had first been incubated for $48 \mathrm{~h}$ in supplemented RPMI 1640 in the presence of concanavalin A $(2.5 \mu \mathrm{g} / \mathrm{ml})$ and lipopolysaccharide $(5 \mathrm{\mu g} / \mathrm{ml})$ at $37^{\circ} \mathrm{C}$. During the final $2.5 \mathrm{~h} \mathrm{of}$ this incubation, cells were adjusted to colcemid $\left(2 \times 10^{-7} \mathrm{~mol} / \mathrm{l}\right)$ to fix the mitotic apparatus. Cells were harvested and $2 \mathrm{ml}$ of $\mathrm{KCl}$ $(75 \mathrm{mmol} / \mathrm{l})$ was added drop-wise, and then incubated at $37^{\circ} \mathrm{C}$ for $20 \mathrm{~min}$. Cells were next pelleted and $2 \mathrm{ml}$ of a freshly prepared fixative ( $3: 1$, absolute methanol: glacial acetic acid) was added. Incubation was continued for $15 \mathrm{~min}$ at $4^{\circ} \mathrm{C}$ after which cells were pelleted, resuspended in a minimum volume of fixative, and dropped onto glass slides from a height of approximately $10 \mathrm{~cm}$. Slides were air dryed, stained in $2 \%$ Giemsa (Sigma), $67 \mathrm{mmol} / 1 \mathrm{NaHPO}_{4}, 67 \mathrm{mmol} / \mathrm{l}$ $\mathrm{KH}_{2} \mathrm{PO}_{4}$ and chromosomes examined using a Nikon light microscope (Nikon, Garden City, New York).

\section{Statistical analysis}

All data are expressed as mean \pm SEM. Statistical significance of differences were determined by Student's t-test for independent samples (two-tailed).

\section{Results}

\section{Impairment of humoral and cellular immunity in alloxan-} and STZ-induced diabetic mice

The immune competence of alloxan- and STZ-induced diabetic mice was assessed at the humoral and cellular levels. Humoral immune function was determined by the ability of diabetic spleen cells to mount a primary antibody response to sheep red blood cells or a mitogenic response to concanavalin $A$ upon challenge in vitro (Fig. 1). Cellular immune function was evaluated in vivo using the delayed-type hypersensitivity response to the hapten azobenzenearsonate (Fig. 1). In agreement with previous studies [10-12], severe depression of both arms of the immune system $(>50 \%)$ was observed in alloxan- and STZ-induced diabetic mice relative to normal control mice. Equivalent levels of suppression were seen in alloxan- and STZ-diabetic mice. The level of insulin deficiency and metabolic control was also equivalent in STZ- and alloxan-diabetic mice. Pancreatic immunoreactive insulin levels were constant between days $4-10$ after drug injection at $37 \pm 4 \mu \mathrm{g} / \mathrm{g}$ for STZ-diabetic mice and $35 \pm 5 \mu \mathrm{g} / \mathrm{g}$ for alloxan-diabetic mice; $33 \%$ and $31 \%$ respectively of normal levels. Mean glucose levels of all experimental mice were between 25-33 mmol/1. Mean weight loss of experimental mice relative to controls was $8 \%$ for both STZ and alloxan on day 5 after drug administration, and 17\% (STZ) or 16\% (alloxan) on day 10.

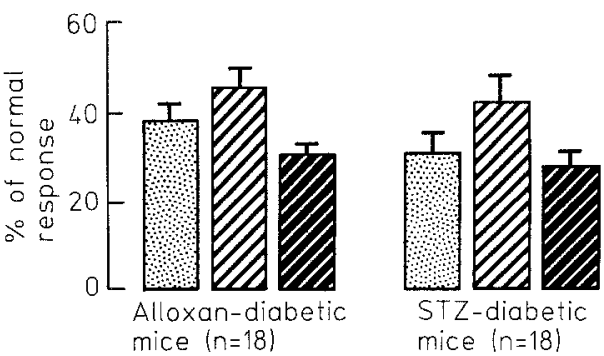

Fig. 1. Impaired humoral and cellular immune responses in diabetic mice. The immune responses of diabetic and normal mice was assessed by evaluating anti-sheep red blood cell plaque forming ( $\square$ ), and conanavalin A mitogenic responses in vitro $(\square)$, and delayedtype hypersensitivity responses to the hapten azobenzenearsonate in vivo (Z). The responses of alloxan and STZ-diabetic mice were assayed on day 5 following drug injection. Drugs were not added to in vitro incubations. Results are expressed as a percentage of the mean response of untreated (normal) mice $\pm \mathrm{SEM}$. Normal responses were: 2561 plaque forming cells $/ 10^{6}$ spleen cells for anti-sheep red blood cells assay; $98,451 \mathrm{cpm}$ for concanavalin A stimulated proliferation; and $26 \times 10^{-2} \mathrm{~mm}$ for delayed-type hypersensitivity measurements. $p<0.001, n=18$ for all tests of diabetic compared to normal mice.

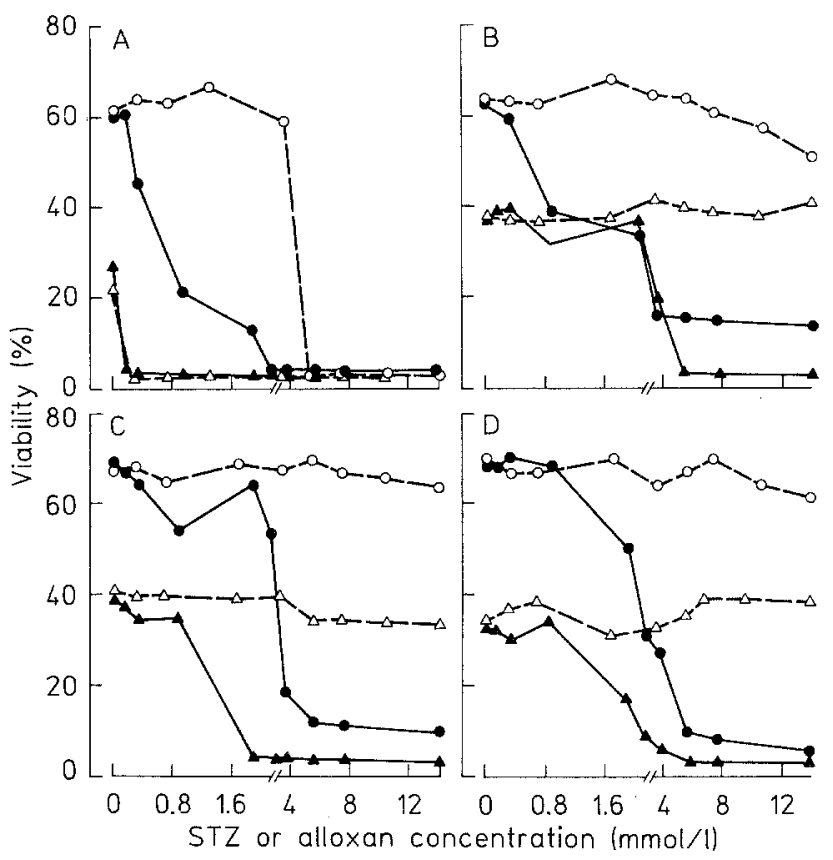

Fig. 2A-D. Alloxan and STZ toxicity in vitro. The toxicity of alloxan (open symbols) or STZ (closed symbols) were measured in vitro on isolated A pancreatic islets, B splenocytes, $\mathbf{C}$ thymocytes, and $\mathbf{D}$ adherent splenic macrophages. Cell viability was measured after 2-day (circles) and 5-day (triangles) incubations with drug. Results presented are the means of experiments performed in quadruplicate. Mean $\pm \mathrm{SEM}<3.0 \%$ for all points, $n=6$

\section{Effect of alloxan and STZ on the viability and function of lymphoid cells}

In light of previously reported direct suppressive effects of STZ on cellular immune responses, we undertook an analysis of the effects of alloxan and STZ, over a wide range of concentrations, on both cellular viability and relevant functional immune properties of lymphoid cells. 
Table 1. Chromosomal abnormalities induced by alloxan or STZ

\begin{tabular}{|c|c|c|c|c|c|}
\hline Treatment & $\begin{array}{l}\% \text { Cells } \\
\text { aberrant }\end{array}$ & $\begin{array}{l}\text { Chromatic } \\
\text { exchanges }\end{array}$ & $\begin{array}{l}\text { Chromatic } \\
\text { breaks }\end{array}$ & $\begin{array}{l}\text { Other } \\
\text { aberrations }\end{array}$ & $\begin{array}{l}\text { Mitotic }{ }^{\mathrm{a}} \\
\text { index }\end{array}$ \\
\hline None & 2 & 0 & 0 & 0 & 0.7 \\
\hline \multicolumn{6}{|c|}{ Alloxan exposure 2 days in vitro $(\mathrm{mmol} / \mathrm{l})$} \\
\hline 1.0 & 3 & 0 & 3 & 0 & 0.6 \\
\hline 2.0 & 3 & 0 & 2 & 2 & 1.4 \\
\hline 4.0 & 2 & 0 & 2 & 0 & 0.7 \\
\hline 5.0 & 3 & 0 & 3 & 0 & 0.9 \\
\hline 7.0 & 6 & 0 & 9 & 2 & 1.1 \\
\hline \multicolumn{6}{|c|}{ STZ exposure 2 days in vitro $(\mathrm{mmol} / \mathrm{l})$} \\
\hline 0.4 & 2 & 1 & 3 & 0 & 1.6 \\
\hline 1.0 & 4 & 0 & 3 & 1 & 1.2 \\
\hline 2.0 & 14 & 3 & 13 & 9 & 1.1 \\
\hline 3.0 & 23 & 9 & 23 & 26 & 1.0 \\
\hline 4.0 & $0^{b}$ & $0^{b}$ & $0^{\mathrm{b}}$ & $0^{\mathrm{b}}$ & $<0.2$ \\
\hline \multicolumn{6}{|c|}{ Alloxan administration 2 days in vivo $(n=8)$} \\
\hline $50 \mathrm{mg} / \mathrm{kg}$ & 4 & 0 & 3 & 1 & 1.4 \\
\hline \multicolumn{6}{|c|}{ STZ administration 2 days in vivo $(n=8)$} \\
\hline $150 \mathrm{mg} / \mathrm{kg}$ & 10 & 2 & 8 & 6 & 1.5 \\
\hline
\end{tabular}

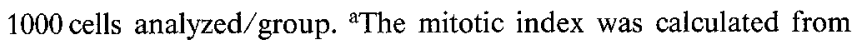
the number of mitotic figures $/ 1000$ cells counted. ${ }^{b}$ Viability $<20 \%$

Table 2. Distribution of splenic lymphocyte populations in normal versus alloxan-diabetic mice

\begin{tabular}{llll}
\hline $\begin{array}{l}\text { Lymphocyte } \\
\text { Class }\end{array}$ & $\begin{array}{l}\text { Cells stained } \\
140,000\end{array}$ & $\begin{array}{l}\% \text { of total } \\
\text { spleen cells }\end{array}$ & $\begin{array}{l}\% \text { of splenic } \\
\text { T cells }\end{array}$ \\
\hline B cells $(n=8)$ & & & \\
$\quad$ Normal & $20,984 \pm 348$ & 52 & - \\
$\quad$ Diabetic & $21,072 \pm 467$ & 53 & - \\
T cells $(n=8)$ & & & \\
$\quad$ Normal & $10,032 \pm 261$ & 25 & - \\
$\quad$ Diabetic & $8,744 \pm 297$ & 22 & - \\
Lyt 1+ T cells $(n=8)$ & & & \\
$\quad$ Normal & $23,908 \pm 621$ & - & 60 \\
$\quad$ Diabetic & $22,536 \pm 811$ & - & 56 \\
Lyt 2 ${ }^{+}$T cells $(n=8)$ & & & \\
$\quad$ Normal & $6,740 \pm 148$ & - & 17 \\
$\quad$ Diabetic & $6,020 \pm 156$ & - & 15 \\
\hline
\end{tabular}

Data on the staining of $\mathrm{T}$ cells and $\mathrm{T}$-cell subsets have been corrected for staining detected in the absence of T-cell specific antibody markers

The effects of alloxan and STZ on the viability of pancreatic, splenic, thymic, and adherent macrophage populations are shown in Figure 2. Both drugs were toxic for purified pancreatic islet cells at $>0.2 \mathrm{mmol} / 1$ in 5 day incubations (Fig. 2A). Significant toxicity was also seen after 2 days of incubation, with the toxicitity of STZ being more pronounced than that of alloxan. The toxicity of alloxan and STZ toward spleen, thymus and macrophage cells showed a markedly different though consistent pattern (Fig. 2 B-D). In each instance no alloxan toxicity was detected on days 2 or 5 at any concentration, while STZ toxicity was seen beginning at doses of $1-2 \mathrm{mmol} / \mathrm{l}$.

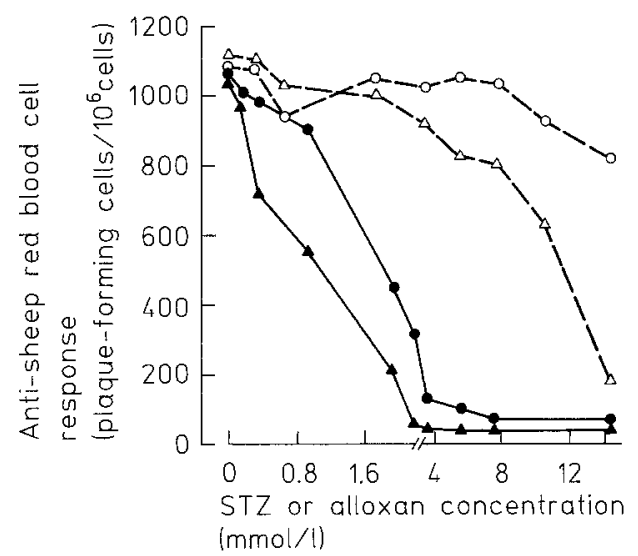

Fig. 3. Effect of alloxan and STZ on the anti-sheep red blood cell plaque-forming response in vitro. Anti-sheep red blood cell plaque responses were conducted in vitro in a 5 -day incubation protocol in the presence of either alloxan (open symbols) or STZ (closed symbols). Drugs were present for either the entire 5-day incubation (triangles) or were added for only the last 2 days of culture before assay (circles). The means of experiments performed in triplicate are presented. Mean \pm SEM $<8.0 \%$ for all points, $n=6$

The effects of alloxan and STZ on the function of cells, which govern immunity, were assesed by monitoring exposure to a range of drug concentrations in vitro on: (1) the sheep red blood cell antibody response (Fig. 3); (2) the proliferative response of splenocytes to the T-cell mitogens concanavalin A and phytohaemagglutinin (Fig. 4A, B), and the B-cell mitogen lipopolysaccharide (Fig. 4C); (3) the synthesis of interleukin-2 by concanavalin $\mathrm{A}$ activated splenocytes (Fig. $5 \mathrm{~A}$ ); and (4) the synthesis of interleukin-l by lipopolysaccharide stimulated splenic macrophages (Fig. 5 B). In agreement with the preceding results, STZ routinely inhibited cellular functions at concentrations $>0.4 \mathrm{mmol} / \mathrm{l}$, while alloxan had no effect at concentrations $<10 \mathrm{mmol} / \mathrm{l}$.

\section{Mechanism of STZ and alloxan toxicity}

Despite their differences in structure, the mechanisms of alloxan and STZ toxicity on pancreatic islet cells are believed to be similarly mediated by oxidative DNA strand breakage [9]. The incidence of chromosomal abnormalities in splenocytes upon exposure to alloxan or STZ, in vitro or in vivo, is presented in Table 1 . Only STZ induced chromosomal aberrations on in vitro exposure; these were seen at concentrations $>2 \mathrm{mmol} / \mathrm{l}$. Spleen cells isolated from mice 2 days following injection with diabetogenic doses of alloxan $(1.1 \mathrm{mmol} / \mathrm{l})$ or STZ $(1.8 \mathrm{mmol} / \mathrm{l})$ were analyzed in a similar manner. Spleen cells from alloxan-induced diabetic mice showed no signs of abnormalities while those from STZ-induced diabetic mice exhibited low but significant levels of chromosomal abnormalities $(p<0.005$, $n=8$ ). 


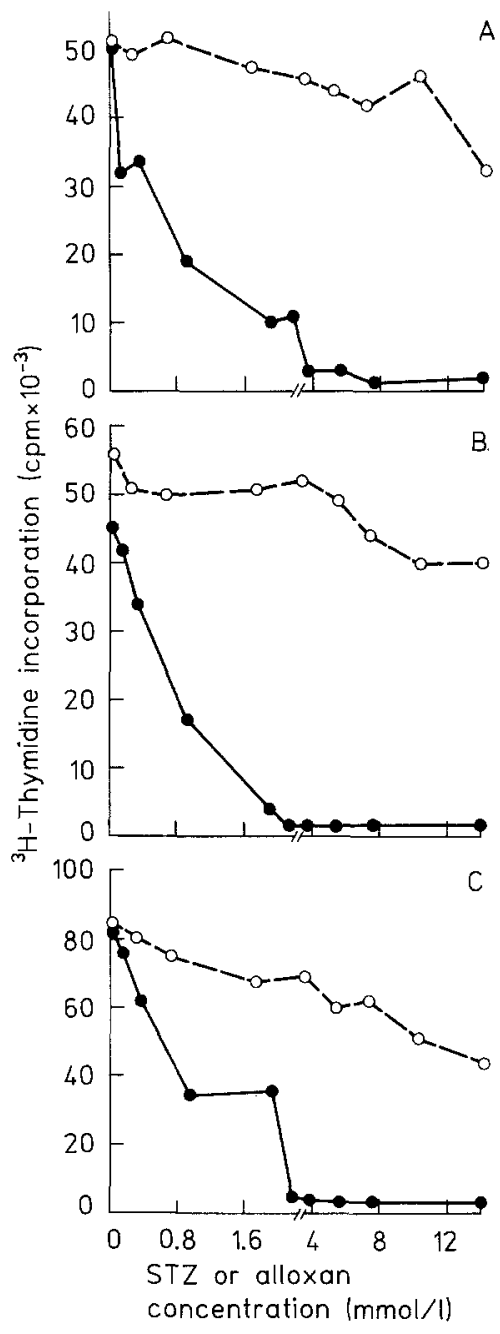

Fig.4. Effect of alloxan and STZ on the mitogenic response of splenocytes in vitro. Proliferative responses of splenocytes to the mitogens A phytohaemagglutinin, $\mathbf{B}$ concanavalin $\mathbf{A}$ and $\mathbf{C l i p o p o l y -}$ saccharide were conducted in vitro in the presence of either alloxan (open symbols) or STZ (closed symbols). Reactions were pulsed with ${ }^{3} \mathrm{H}$-thymidine for the final $8 \mathrm{~h}$ of $48 \mathrm{~h}$ incubations. The mean ${ }^{3} \mathrm{H}$-thymidine incorporation of experiments conducted in quadruplicate are presented. Mean $\pm \mathrm{SEM}<4.0 \%$ for all points, $n=6$

\section{Immune response of insulin-treated diabetic mice}

Final assessment of the usefulness of a drug-based model for studying the immune competence of diabetic mice was accomplished by comparing the responsiveness of normal, alloxan- and STZ-diabetic mice to that of insulin-treated alloxan- and STZ-diabetic mice. The degree of metabolic control achieved in mice treated for 4 days with insulin was determined by plasma glucose levels, weight measurements, and glucose tolerance tests. Insulin-treated alloxan- and STZ-diabetic mice exhibited nearly normal levels of control. Plasma glucose levels were reduced on insulin treatment to within $10 \%$ of normal: $135 \pm 12 \mathrm{mmol} / 1$ for alloxan and $131 \pm$ $16 \mathrm{mmol} / 1$ for STZ. Alloxan-treated mice experienced a $4 \%$ weight gain and STZ-treated mice a 3\% weight gain over the first 4 days. Treated alloxan and STZ-diabetic

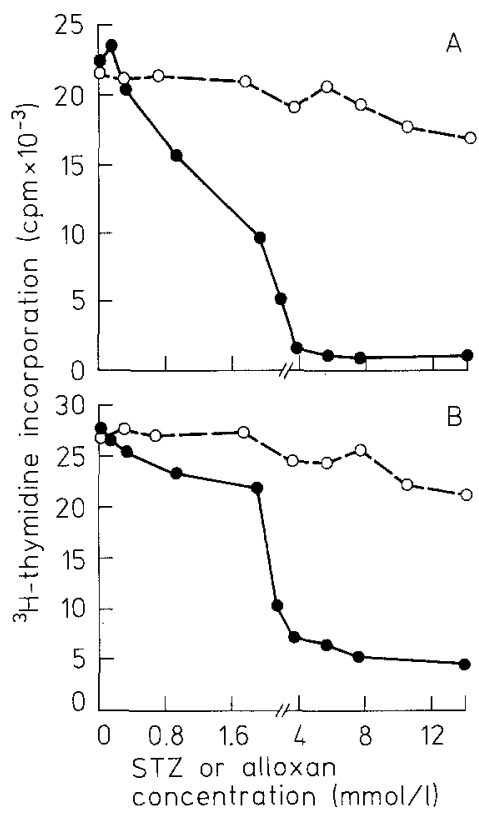

Fig.5. Effect of alloxan and STZ on the production of interleukin-1 and interleukin-2 in vitro. A Interleukin-2 synthesis by concanavalin A stimulated splenocytes. B Interleukin-1 synthesis by lipopolysaccharide stimulated macrophages. Incubations were conducted for $48 \mathrm{~h}$ in the presence of either alloxan (open symbols) or STZ (closed symbols). Results are presented as the mean ${ }^{3} \mathrm{H}$-thymidine incorporation of appropriate indicator cells and were performed in triplicate. Mean \pm SEM $<3.0 \%$ for $\mathbf{A}$ and $<4.0 \%$ for $\mathbf{B}, n=6$

mice had equivalent yet slightly elevated glucose tolerance responses. The responses of normal mice were $146 \pm 11 \mathrm{mmol} / 1$, while insulin-treated alloxan-diabetic mice were $185 \pm 19 \mathrm{mmol} / 1$ and insulin-treated STZdiabetic mice were $172 \pm 12 \mathrm{mmol} / 1$ ( $n=18$ for all determinations).

Immune competence was assayed, as described in Figure 1, for in vitro concanavalin A mitogenesis and anti-sheep red blood cell responses, and in vivo by delayed-type hypersensitivity responses. The results indicate that insulin-treated alloxan-diabetic mice respond at normal levels (Fig. 6), thus reinforcing the conclusion drawn previously that a diabetogenic dose of alloxan $(50 \mathrm{mg} / \mathrm{kg})$ does not itself cause immune dysfunction. In contrast, the response of insulin-treated STZ-diabetic mice remained slightly impaired relative to normal levels. Although insulin management reversed the STZdiabetic effect by 70 to $80 \%$ of normal and returned blood glucose levels to the normal range, the lack of a complete recovery indicates that diabetogenic doses of $\mathrm{STZ}(150 \mathrm{mg} / \mathrm{kg})$ result in direct, irreversible damage to components of the immune system.

\section{Distribution of splenic lymphocyte populations in alloxan-diabetic mice}

In light of recent reports of severe T-cell lymphocytopenia in the BB diabetic rat [29] and a reduced splenic weight in alloxan-diabetic mice $[11,14,28]$, we also in- 


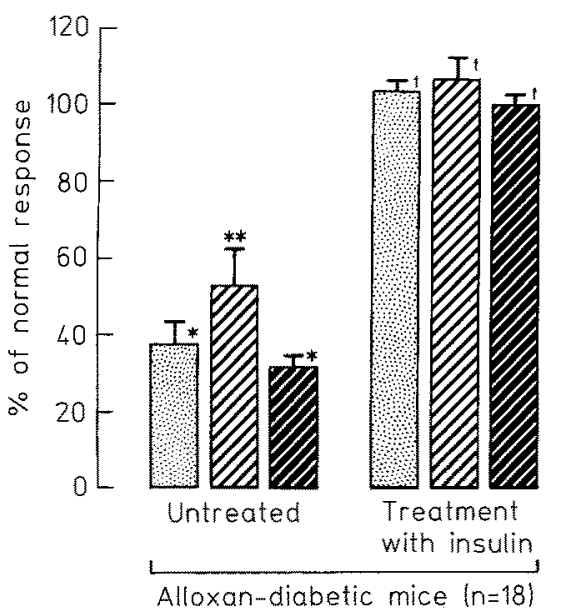

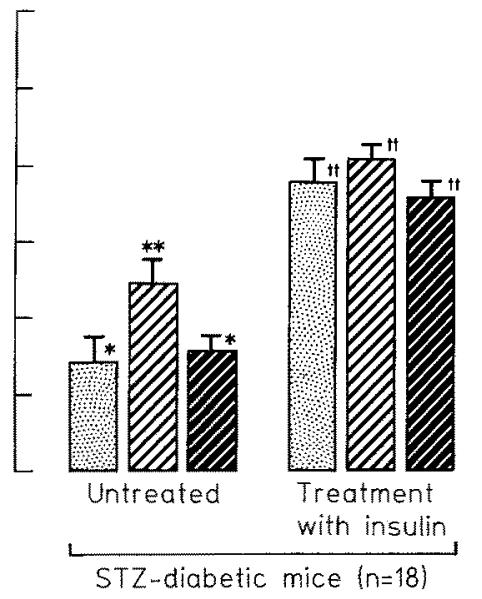

Fig. 6. Humoral and cellular immune responses of insulin-treated diabetic mice. Anti-sheep red blood cells plaque forming responses (7), concanavalin A proliferation $(\square)$, and delayed-type hypersensitivity responses $(\mathbb{Z})$ were conducted on alloxan-diabetic and insulin-treated alloxan-diabetic mice, and STZ-diabetic and insulin-treated STZ-diabetic mice as described in Figure $1 . n=18$ for all groups. *, $p<0.001 ; * *, p<0.002 ;+, p<0.05 ;++, p<0.02$ vestigated the possibility that alloxan-diabetic mice have an altered ratio of $\mathrm{B}$ - and T-cell subsets. Fluorescence analysis of spleens from 5-day alloxan-diabetic mice displayed a normal pattern of B-and T-cell subset proportions (Table 2). Histological analysis of alloxandiabetic spleen and thymus (not shown) demonstrated a normal morphology on day 2 and arteriolar thickening associated with establishment of diabetes on day 5 . No necrotic lesions were detected on days 2 or 5 .

\section{Discussion}

The results of this study indicate that the use of alloxan to induce the diabetic syndrome provides a useful model to study the immune system in diabetic mice. Studies in vivo and in vitro demonstrated that even at greater than ten times the diabetogenic dose $(1.1 \mathrm{mmol} / 1)$ alloxan was neither directly toxic for lymphoid cells nor did it irreversibly impair cellular functions critical to generation of the immune response. Most importantly, normal immune responses were restored in alloxan-diabetic mice which were managed by thrice daily injections of insulin. Results supportive of this hypothesis have also been reported by Ptak et al. [11].

In contrast, the diabetogeneic drug STZ displayed significant lymphoid cell toxicity in vitro, and impaired lymphoid cell mediated functions in vitro and in vivo at doses equivalent to or less than those required for the establishment of diabetes $(1.8 \mathrm{mmol} / 1)$. Management of STZ-diabetic mice with insulin failed to completely restore immune impairment. Results of a similar nature have been reported by Nichols et al. [14] for STZ depression of blastogenic and cytolytic responsiveness.

Therefore, while the in vitro toxicity of STZ for pancreatic islet B cells is more pronounced than on lymphoid cells, the window of cross-sensitivity in vivo overlaps to an extent which results in significant non-specific lymphoid toxicity. Our karyotype analyses suggest that the primary mechanism of STZ lymphoid toxicity is via oxidative driven mutagenesis in rapidly dividing cells. These results stress caution in the use of STZ for the study of other pathological phenomena associated with diabetes and in the treatment of pancreatic islet cell carcinomas.

The window of alloxan cross-sensitivity as measured in vitro is considerably larger than with STZ. Coupled with the three-fold lower diabetogenic dose of alloxan relative to STZ, this window is maintained in vivo and allows for B-islet cell destruction in the absence of significant lymphoid toxicity. One explanation for why insulin restores immune competence in alloxan-induced diabetes may be simply that of improved glucose transport in lymphocytes which must proliferate and metabolize rapidly following activation with antigen.

Acknowledgements. Dr. Gaulton is the recipient of a National Institutes of Health postdoctoral fellowship No.5-F32-CA-06948-02. Supported by grant Al 20842 from the National Institutes of Health.

\section{References}

1. Johnson JE III (1983) Infection and diabetes. In: Ellenberg M, Rifkin H (eds) Diabetes millitus: Theory and practice. McGrawHill, New York, pp 734-7452

2. Louria DB (1967) Deep-seated mycotic infections, allergy to fungi and mycotoxins. N Engl $J$ Med 277: 1065-1071

3. MacCuish AC, Jordan J, Campbell CJ, Duncan LJP, Irvine WJ (1974) Cell-mediated immunity to human pancrease in diabetes mellitus. Diabetes 23:693-697

4. Buse JB, Rowley RF, Eisenbarth GS (1982) Disordered cellular immunity in type I diabetes of man and the BB rat. Surv Immunol Res 1: 339-351

5. Coleman DL (1979) Diabetes mellitus in rodents. In: Andrews EJ, Ward BC, Altman NH (eds) Spontaneous animal models of human disease, vol 1. Academic Press, New York, pp 126 131

6. Rerup CC (1970) Drugs producing diabetes through damage of the insulin secreting cells. Pharm Rev 22: 485-518

7. Weiss RB (1982) Streptozotocin: a review of its pharmacology, efficacy, and toxicity. Cancer Treatment Reports 66: 427-436

8. Malaisse-Lagae F, Sener A, Malaisse WJ (1981) Biochemical basis of a species difference in sensitivity to alloxan. FEBS Lett 133: $181-182$

9. Yamamoto H, Uchigata Y, Okamoto $H$ (1981) Streptozotocin and 
alloxan induce DNA strand breaks and poly(ADP-ribose) synthetase in pancreatic islets. Nature 294: $284-286$

10. Ptak W, Hanczakowska M, Rozycka R, Rozycka D (1977) Impaired antibody responses in alloxan diabetic mice. Clin Exp Immunol 29: 140-146

11. Ptak W, Czarnik Z, Hanczakowska M (1975) Contact sensitivity in alloxan-diabetic mice. Clin Exp Immunol 19: 319-325

12. Mahmoud AAF, Rodman HM, Mandel MA, Warren KS (1976) Induced and spontaneous diabetes mellitus and suppression of cell-mediated immunologic responses. J Clin Invest 57: 362-367

13. Nevalainen DE, Hoftiezer U (1977) The response of C3H mice to streptozotocin. I. Thymic depression and leukocyte toxicity. Am J Med Technol 43: 417-418

14. Nichols WK, Spellman JB, Vann LL, Daynes RA (1979) Immune responses of diabetic animals: direct immunosuppressant effects of streptozotocin in mice. Diabetologica $16 ; 51-57$

15. Hyvarinen A, Nikkila E (1962) Specific determination of blood glucose with 0-toluidine. Clin Chim Acta 1: 140-143

16. Yoon JW, Onodera T, Nokins AL (1978) Virus-induced diabetes mellitus. XV. Beta cell damage and insulin-dependent hyperglycemia in mice infected with Coxsackie B4. J Exp Med 148: $1068-1080$

17. Onodera T, Toniolo A, Ray UR, Jenson AB, Knazek RA, Notkins AL (1981) Virus-induced diabetes mellitus XX. Polyendocrinopathy and autoimmunity. J Exp Med 153: 1457-1473

18. Bernstein SE (1966) Physiological characteristics. In: Green EL (ed) Biology of the laboratory mouse, 2nd edn. McGraw-Hill, New York, pp 337-350

19. Lee JM, DeWitt S Jr (1952) Studies in alloxan metabolism. J Biol Chem 197: 205-214

20. Lacy PE, Kostianovsky M (1967) Method for the isolation of intact islets of langerhans from the rat pancreas. Diabetes 16:35-39

21. Cowing C, Schwartz BD, Dickler HB (1978) Macrophage Ia antigens. I. Macrophage populations differ in their expression of Ia antigens. J Immunol 120: 378-384

22. Grankvist K, Lernmark A, Taljedal I-B (1977) Microscope photo- metric analyses of trypan blue uptake by pancreatic islet cells in suspension. Biochem J 162: 19-24

23. Cunningham AJ (1965) A method of increased sensitivity for detecting single antibody-forming cells. Nature 207: 1106-1107

24. Eardley DD, Murphy DB, Kemp JD, Shen FW, Cantor H, Gershon RK (1980) Ly-1 inducer and ly-1,2 acceptor T cells in the feedback suppressor circuit bear an I-J subregion determinant. Immunogenetics 11: 549-553

25. Gillis S, Ferm MM, Ou W, Smith KA (1978) T cell growth factor: parameters of production and a quantitative microassay for activity. J Immunol 120: 2027-2032

26. Mizel SB, Oppenheim JJ, Rosenstreich DL (1978) Characterization of lymphocyte-activating factor (LAF) produced by the macrophage cell line P388Dl. 1. Enhancement of LAF production by activated Tlymphocytes. J Immunol 120: 1497-1503

27. Bach BA, Sherman L, Benacerraf B, Greene MI (1978) Mechanisms of regulation of cell-mediated immunity. II. Induction and suppression of delayed-type hypersensitivity to azobenzene-arsonate-coupled syngeneic cells. J Immunol 121: 1460-1468

28. Nichols WK, Spellmann JB, Daynes RA (1978) Immune responses of diabetic animals: comparison of genetically obese and streptozotocin-diabetic mice. Diabetologica 14: 343-349

29. Jackson R, Rassi N, Crump T, Haynes B, Eisenbarth GS (1981) The BB Diabetic rat: profound T-cell lymphocytopenia. Diabetes $30: 887-889$

Received: 1 October 1984

and in revised form: 21 June 1985

Dr. Glen Gaulton

Department of Pathology

University of Pennsylvania

Medical School

3400 Spruce Street

Philadelphia, PA 19104

USA 